\title{
IAMJ
}

INTERNATIONAL

AYURVEDIC

MEDICAL JOURNAL

ISSN: 2320-5091

Impact Factor: 6.719

\section{A COMPARATIVE CLINICAL STUDY TO EVALUATE THE EFFICACY OF ABHA GUGGULU AND YOGARAJA GUGGULU IN JANU SANDHIGATA VATA}

\author{
$\underline{\text { Archana B.H. Jadav }}^{1}, \underline{\text { Susheel Shetty }}^{2}$ \\ ${ }^{1}$ Final Year PG Scholar, ${ }^{2}$ Professor, Guide and HOD; \\ Dept of Kayachikitsa, Alva's Ayurveda Medical College, Moodbidri, Karnataka, India
}

Corresponding Author: archanajadav18@gmail.com

https://doi.org/10.46607/iamj0409092021

(Published Online: September 2021)

Open Access

(C) International Ayurvedic Medical Journal, India 2021

Article Received: 20/08//2021 - Peer Reviewed: 02/09/2021 - Accepted for Publication: 03/09/2021

\section{Check for updates}

\begin{abstract}
Mobility is the basic character of life that depends on the structural as well as the functional character of the body. As age advances, while proper nutrition is not available, the body loses its qualitative capacity for structure and function. Janu Sandhigata Vata has been explained classically by Acharyas and its lakshanas are Vata Poornadhrithi Sparsha, Sandhi Shotha, Sandhi Shoola and the presence of Vedana during Prasarana and Aakunchana. The lakshanas of Janu Sandhigata Vata is found to be congruent with Osteoarthritis of the Knee. Research statistics have shown that in India, 22\% of the population shows Osteoarthritis and females slightly dominate in the incidence. Abha Guggulu and Yogaraja Guggulu are two formulations that contain the drugs of Vatahara, Shothahara, Vedanasthapaka property which will help in the management of Janu Sandhigata Vata. Methods: It was a single-blind randomized comparative clinical trial. The study was conducted on 40 subjects for 30 days. Observations were analyzed and findings were evaluated by using statistical methods. Results: The severity of symptoms markedly reduced in both the groups which is statistically significant and on comparing the effect between Abha Guggulu and Yogaraja Guggulu, there was no statistical difference obtained. Conclusion: The result suggests that both Abha Guggulu and Yogaraja Guggulu had a significant effect on Janu Sandhigata Vata There was no significant difference in the effect of Abha Guggulu and Yogaraja Guggulu.
\end{abstract}

Keywords: Janu Sandhigata Vata, Abha Guggulu, Yogaraja Guggulu 


\section{INTRODUCTION}

Ayurveda is a holistic medicine that serves humans. Signs of well-being or independence are well represented in this ancient treatise in this fast-developing technological era, while people are motivated by new advanced medical science and technology, the oldest Ayurvedic science has retained its position in the science of life, which retains its principles of health. Mobility is the basic character of life that depends on the structural as well as the functional character of the body. As age advances, while proper nutrition is not available, the body loses its qualitative capacity for structure and function. Janu Sandhigata Vata has been explained classically by Acharyas and its lakshanas are Vata Poornadhrithi Sparsha, Sandhi Shotha, Sandhi Shoola and the presence of Vedana during Prasarana and Aakunchana ${ }^{1}$.n According to Ayurveda, all the dhatus are undergoing Kshaya in the $4^{\text {th }}$ decade of life. This leads to vata prakopaka and the individual is susceptible to many illnesses. Janu Sandhigata Vata is having a higher incidence among them. It cripples the individual progressively without killing. Janu Sandhigata Vata is a shoola and Shotha Pradhan Vataja Nanatmaja Vyadhi; affecting the locomotor system; leaving the person disabled and making him unable to perform his daily routine activities. Being afflicted with Pakalitha vata; san$d h i$ 's are one of the forms of marma and forms a part of Madhyama Roga Marga. Thus, the presence of Madyama Roga Marga; vata dosha and Dhatuksaya causes the disease to be Kastasadya or Krucchrasadya. The lakshanas of Janu Sandhigata Vata is found to be congruent with Osteoarthritis of the Knee. Osteoarthritis is a degenerative disorder in which there is a biochemical breakdown in synovial joints, characterized by primary degenerative changes in the articular cartilage, further leading to joint stiffness, pain, and loss of mobility ${ }^{2}$. Research statistics have shown that in India, 22\% of the population shows Osteoarthritis and females slightly dominate in the incidence ${ }^{3}$. In Ayurveda classics, there is proven effects of Shamanoushadi for Janu Sandhigata Vata like Kaishor Guggulu, Gokshuradi Guggulu, Shahada Guggulu ${ }^{6}$ etc. Guggulu is said to be sroto Sho- dhaka and has been shown to have anti-inflammatory and anti-arthritis properties by various research workers ${ }^{7}$. Various treatment modalities are present in modern science like usage of analgesics, corticosteroids, NSAID's etc. However, these medications are not as effective as they cause gastric degradation, hepatic and neurotoxicity with adverse effects ${ }^{8}$.

Abha Guggulu explained in Cakradatta was taken as the trial drug, for proving its efficacy in the management of Janu Sandhigata Vata. Yogaraja Guggulu ${ }^{10}$ explained in Bhaishajya Ratnavali has constituents like Chitraka, pippalimula, Gokshura, Ajamoda which are shoolahar and Shothahara and it was taken as a standard drug. This formulation works as Vyadhi pratyaneeka chikitsa; which is safe, economical, easily available and serves as fast-acting treatment in Janu Sandhigata Vata and meets the needs of today. Hence with the present clinical study, Abha Guggulu and Yogaraja Guggulu was taken, and results were compared for better efficacy in Janu Sandhigata vata.

\section{AIM AND OBJECTIVES:-}

1. To evaluate and ascertain the individual effect of Abha Guggulu and Yogaraja Guggulu in Janu Sandhigata Vata.

2. To compare the effect of Abha Guggulu and Yogaraja Guggulu in Janu Sandhigata Vata.

\section{MATERIALS AND METHODS:- SOURCE OF DATA:-}

LITERARY SOURCE:-All the classical books like Brihatrayees and Laghutrayis and modern literature and contemporary text including the website about the disease, drug and procedure was reviewed and documented for the intended study.

DRUG SOURCE:-The raw drugs required were identified and collected from the source of availability and the medicines prepared according to the classical references at Alva's Pharmacy, Mijar.

SOURCE OF SAMPLE:- Patients of either sex attending OPD of Alva's Ayurveda Medical College \& Hospital, Moodbidri and from other available sources who were diagnosed as Janu Sandhigata Vata was selected for the study. 
ETHICAL CLEARANCE:- ICEC/KC/01

pling Method.

METHOD OF SAMPLING:-Simple Random Sam-

Table 1: INTERVENTION: -

\begin{tabular}{|l|l|l|l|l|}
\hline GROUPS & DOSAGE & TIME OF ADMINISTRATION & DURATION OF TREATMENT & ANUPANA \\
\hline $\begin{array}{l}\text { GROUP A } \\
\text { Abha Guggulu }\end{array}$ & $500 \mathrm{mg}$ & Thrice daily after Food & 30 days & Ushnodaka \\
\hline $\begin{array}{l}\text { GROUP B } \\
\text { Yogaraja Guggulu }\end{array}$ & $500 \mathrm{mg}$ & Thrice daily after Food & 30 days & Ushnodaka \\
\hline
\end{tabular}

\section{CRITERIA FOR SELECTION OF PATIENTS: - DIAGNOSTIC CRITERIA:-}

The diagnosis is mainly based upon the lakshanas of Janu Sandhigata Vata mentioned in Ayurvedic texts which will be correlated clinically.

Radiographs will be taken to confirm clinical findings.

\section{INCLUSION CRITERIA}

* Patients showing the classical Lakshanas of Janu Sandhigata Vata like Sandhi Shotha, Sandhi Shoola and Prasarana Akunchana Vedana; with or without Atopa, Janu Sandhi Sparsha Akshamatva and Vata Poorna Dhrithisparsha.

* Patients diagnosed with Janu Sandhigata Vata.

* Previously treated and untreated patients.

EXCLUSION CRITERIA: -

* Patients suffering from diseases like Amavata and other systemic disorders

* Secondary osteoarthritis.

INGREDIENTS OF FORMULATIONS: -

ABHA GUGGULU:- Babbula, Triphala, Trikatu, Guggulu

YOGARAJA GUGGULU: - Chitraka, Yavani, Krishna Jeeraka, Vidanga, Ajamoda, Jeeraka, Pippali Moola, Devadaru, Chavya, Rasna, Gokshura, Dhanyaka, Triphala, Trikatu,Twak, Ushira, Yavakshara, Taleesapatra, Shuddha Guggulu

Method Of Medicine Preparation:-

\section{ABHA GUGGULU :-}

Firstly 2 parts of Shudda Guggulu was taken in a vessel by adding enough water. Then the heating was continued until Guggulu got completely melted. Then 1 part of fine powders of Babbula, Triphala and trikatu was added and mixed well. Then the mixture was allowed to cool down and vatis were prepared which were $500 \mathrm{mg}$ by weight. Finally, it was allowed to dry and was stored in a container.

\section{YOGARAJA GUGGULU:-}

Firstly 2 parts of Shuddha Guggulu was taken in a vessel by adding enough water. Then heating was continued until Guggulu got completely melted. Then $250 \mathrm{~g}$ of fine powders of the rest of the ingredients were added and mixed well. Then the mixture was allowed to cool down and vatis were prepared which is $500 \mathrm{mg}$ by weight. Finally, it was allowed to dry and was stored in a container.

\section{INTERVENTION:-}

The interventions of the clinical study were carried according to the individual groups mentioned above. These groups assigned as Group A and B were treated with Abha Guggulu and Yogaraja Guggulu respectively. The patients fulfilling the criteria for inclusion were randomly assigned into 2groups each comprising of 20 patients.

\section{OBSERVATIONAL PERIOD:-}

Patients were assessed clinically before treatment, on the $16^{\text {th }}$ day and $31^{\text {st }}$ day after treatment.

FOLLOW UP:- after 15 days of the treatment i.e., on the $46^{\text {th }}$ day.

TOTAL STUDY DURATION:- 45 days.

\section{INVESTIGATIONS:-}

Haematological investigations:- Routine blood investigations and X-Ray of the affected Knee -AP and lateral views were done.

\section{ASSESSMENT CRITERIA: -}

Clinical assessments are made for the severity of the disease and the clinical improvement. Grading for the 
severity of individual symptoms was framed for a point scale. The gradings of variables were given along with clinical Performa specially formatted for the study on Janu Sandhigata Vata.

\section{STATISTICAL ANALYSIS:-}

Pre-test and post-test data were compared by using the Wilcoxon sign rank test.

Comparison of Group A and Group B was done by using the Mann-Whitney u test by using IBM SPSS STATISTICS 2.0 software.

\section{DISCUSSION}

AGE:-In this study, the majority of the patients were belonging to the age group of 51-60yrs with $52.5 \%$. This may be due to Vrudavastha is predominant of Vata, the process of degeneration is more seen.

GENDER:- Majority of patients were female about $73.5 \%$. Female hormones affect cushioning cartilage to allow smooth joint movement.

OCCUPATION:- In this present study, the majority of patients were housewives about $72.5 \%$. This may be due to prolonged standing, squatting, and crosslegged sitting.

PRAKRUTI:- Vata Pitta Prakriti patients were dominant which was $42.5 \%$. The reason for this may be as Vata dominant people are prone to this disease.

SAMHANANA:- Among 40 patients in this study, the majority of patients were of Madhyama Samshamana about $60 \%$.

WEIGHT:- Majority of patients present in this study were overweight about $52.5 \%$. Because of which there will be an increase in pressure over the knee joint.

VYAYAMA:- About $67.5 \%$ of patients in this study have Avara Vyayama shakthi. This is due to the disease and age factor. Vata Prakopa.

INCIDENCE OF PAIN:- Among all patients under this study, the incidence of pain was gradual. This is due to degenerative changes in the knee.

CHARACTER OF PAIN:- In this study, $67.5 \%$ of patients had dull aching pain. This is because of cartilage destruction.

COURSE OF PAIN:- Among 40 patients, $40 \%$ experienced progressive type course of pain. This is because of degenerative changes.

AGGRAVATING FACTORS:- In this study, about $72.5 \%$ of patients had evening time aggravation of pain as is said to Vata Prakopa Kala.

RELIEVING FACTORS:- Majority of patients that is $65 \%$ had relief of pain at rest. This may be due to reduced physical activity.

\section{RESULTS}

In the present clinical study, 40 patients of Janu Sandhigata Vata were treated in two groups. In Group A patients were treated with Abha Guggulu and Group B patients were treated with Yogaraja Guggulu respectively.

The signs and symptoms were assessed before treatment, during and after treatment and follow up based on the assessment criteria mentioned earlier.

Table 2: GRADINGS FOR SUBJECTIVE \& OBJECTIVE PARAMETERS:-

\begin{tabular}{|l|l|}
\hline Janu Sandhi Shoola:- & No pain \\
\hline Grade 0 & Mild pain not interfering with activities and sleep \\
\hline Grade 1 & Moderate pain interfering with activities and sleep \\
\hline Grade 3 & Severe pain-reducing activities and sleep \\
\hline Janu Sandhi Stambha:- & \multicolumn{2}{|l|}{} \\
\hline Grade 0 & Absent \\
\hline Grade 1 & Present \\
\hline Janu Sandhi Shotha:- & \\
\hline Grade 0 & No swelling \\
\hline Grade 1 & Slight swelling \\
\hline Grade 2 & Covers well over a bony prominence \\
\hline Grade 3 & Much elevated \\
\hline
\end{tabular}




\begin{tabular}{|c|c|}
\hline \multicolumn{2}{|c|}{ Janu Sandhi Prasarana and Aakunchana Vedana:- } \\
\hline Grade 0 & Full range of joint movement \\
\hline Grade 1 & $>75 \%$ and $<$ full range of joint movement \\
\hline Grade 2 & $50 \%-75 \%$ of the full range of joint movement \\
\hline Grade 3 & Up to $50 \%$ of the full range of joint movement \\
\hline Grade 4 & No movement \\
\hline \multicolumn{2}{|c|}{ Janu Sandhi Atopa:- } \\
\hline Grade 0 & Absent \\
\hline Grade 1 & Palpable \\
\hline Grade 2 & Audible \\
\hline \multicolumn{2}{|c|}{ Janu Sandhi Sparshaakkshamatva:- } \\
\hline Grade 0 & No tenderness \\
\hline Grade 1 & Patients' complaints of joint tenderness \\
\hline Grade 2 & The patient winces on touch \\
\hline Grade 3 & The patient withdraws the affected joint \\
\hline \multicolumn{2}{|c|}{ VAS ( VISUAL ANALOG SCALE):- } \\
\hline Grade 0 & $0 \mathrm{~cm}$ \\
\hline Grade 1 & $1-3 \mathrm{cms}$ \\
\hline Grade 2 & $4-6 \mathrm{cms}$ \\
\hline Grade 3 & $7-10 \mathrm{cms}$ \\
\hline \multicolumn{2}{|c|}{ WOMAC O.A INDEX:- } \\
\hline Grade 0 & None $(0)$ \\
\hline Grade 1 & $\operatorname{Mild}(0-24)$ \\
\hline Grade 2 & Moderate (25-48) \\
\hline Grade 3 & Severe (49-72) \\
\hline Grade 4 & Extreme(73-96) \\
\hline
\end{tabular}

Pre-test and post-test data were compared by using the Wilcoxon sign rank test. Comparison of Group A and Group B was done by using the Mann-Whitney u test by using IBM SPSS STATISTICS 2.0 software.

TABLE 3: STATISTICAL RESULT OF INDIVIDUAL ASSESSMENT CRITERIA: -

\begin{tabular}{|c|c|c|c|c|c|c|c|c|c|}
\hline $\begin{array}{l}\text { Assessment } \\
\text { criteria }\end{array}$ & Group & $\begin{array}{l}\text { BT } \\
\text { Mean }\end{array}$ & $\begin{array}{l}\text { AT } \\
\text { Mean }\end{array}$ & M.D & $\begin{array}{l}\text { Effect of treat } \\
\text { ment }(\%)\end{array}$ & S.D & Z-value & P-value & Rmks \\
\hline \multirow[b]{2}{*}{ Shoola } & A & 1.65 & 0.65 & 1 & $63.63 \%$ & 0.81 & 3.31 & 0.001 & HS \\
\hline & B & 1.55 & 0.70 & 0.85 & $58.06 \%$ & 0.80 & 3.6 & 0.00 & HS \\
\hline \multirow[b]{2}{*}{ Stambha } & A & 1.0 & 0.35 & 0.65 & $75 \%$ & 0.48 & 3.60 & 0.00 & HS \\
\hline & B & 1.00 & 0.40 & 0.6 & $70 \%$ & 0.50 & 3.46 & 0.001 & HS \\
\hline \multirow[b]{2}{*}{ Shotha } & A & 1.30 & 0.40 & 0.9 & $76.92 \%$ & 0.59 & 3.81 & 0.00 & HS \\
\hline & B & 1.50 & 0.55 & 0.95 & $80 \%$ & 0.60 & 4.14 & 0.00 & HS \\
\hline \multirow{2}{*}{$\begin{array}{l}\text { Prasarana } \\
\text { Aakunchana Vedana }\end{array}$} & A & 2.00 & 0.85 & 1.3 & $65 \%$ & 0.58 & 3.96 & 0.00 & HS \\
\hline & B & 1.95 & 0.75 & 1.2 & $71.79 \%$ & 0.78 & 4.02 & 0.00 & HS \\
\hline \multirow[b]{2}{*}{ Atopa } & A & 1.25 & 1.25 & 20 & 0 & 0.0 & 0.0 & 1 & IS \\
\hline & B & 1.15 & 1.15 & 0 & 0 & 0.36 & 0.00 & 1 & IS \\
\hline \multirow[b]{2}{*}{ VAS } & A & 1.90 & 0.70 & 1.2 & $65.78 \%$ & 0.80 & 3.87 & 0.00 & HS \\
\hline & B & 1.80 & 0.60 & 1.25 & $69.44 \%$ & 0.68 & 4.17 & 0.00 & HS \\
\hline \multirow[b]{2}{*}{ WOMAC } & A & 3.0 & 2.30 & 0.7 & $30 \%$ & 0.58 & 2.91 & 0.00 & HS \\
\hline & B & 2.90 & 2.20 & 0.7 & $25.86 \%$ & 0.41 & 3.07 & 0.001 & HS \\
\hline
\end{tabular}




\section{DISCUSSION ON RESULTS}

\section{EFFECT OF TREATMENT ON SHOOLA: -}

The effect of treatment on Shoola within the group, before and after treatment also at follow up with pvalue $(<0.001)$ was statistically highly significant in both the groups.

On comparing the groups, the p-value $(=0.86)$ revealed statistically no significant difference between the groups.

Percentage-wise relief on Shoola in Group A was $63.63 \%$ to that of Group B was $58.06 \%$.

\section{EFFECT OF TREATMENT ON STAMBHA: -}

The effect of treatment on Stambha within the group, before and after treatment also after following up the p-value $(<0.001)$ was statistically highly significant.

On comparing between the groups, the p-value $(=1)$ revealed statistically no significant differences between the groups.

Percentage-wise relief on Stambha in Group A was $75 \%$ with that of Group B was $70 \%$.

\section{EFFECT OF TREATMENT ON SHOTHA : -}

The effect of treatment on Shotha within the group. before and after treatment also at follow up the pvalue $(<0.001)$ was statistically highly significant in both the groups.

On comparing between the groups, the p-value $(=1.500)$ revealed no significant differences between the groups.

Percentage-wise relief on Shotha in Group B was $80 \%$ whereas in Group A was about $76.92 \%$.

EFFECT OF TREATMENT ON PRASARANA AAKUNCHANA VEDANA: - The effect of treatment on Prasarana Aakunchana Vedana within the group, before and after treatment and at follow up with p-value $(<0.001)$ was statistically highly signifi- cant in both the groups.

On comparing between the groups, the p-value $(=0.560)$ revealed statistically no significant differences between the groups.

Percentage-wise relief on Prasarana Aakunchana in Group B was $71.79 \%$ with that of Group A was $65 \%$.

\section{EFFECT OF TREATMENT ON ATOPA: -}

The effect of treatment on Atopa within the group before and after treatment and at follow up was not significant with p-value $(=1.000)$ of Group A and Group B.

On comparing between the groups, the p-value $(=1.000)$ revealed statistically no significant differences between the groups.

There was 0\% relief on Atopa in both groups.

\section{EFFECT OF TREATMENT ON VAS: -}

The effect of treatment on VAS within the group, before and after treatment also at follow up, the pvalue $(<0.001)$ was statistically highly significant in both the groups.

On comparing between the groups, the p-value $(=1.000)$ revealed statistically no significant differences between the groups.

Percentage-wise relief in Group B was $69.44 \%$ to that $65.78 \%$ in Group A in VAS.

\section{EFFECT OF TREATMENT ON WOMAC:-}

The effect of treatment on WOMAC within the group, before and after treatment also at follow up with p-value $(<0.001)$ was statistically highly significant in both the groups.

On comparing between the groups, the p-value $(=1.000)$ revealed statistically no significant between the groups.

Percentage-wise relief in WOMAC in Group A was $30 \%$ to that of $25.86 \%$ in Group B.

TABLE 4: DISCUSSION ON COMPARATIVE EFFECT OF TREATMENT IN GROUP A \& GROUP B:-

\begin{tabular}{|l|l|l|l|l|l|l|}
\hline Symptoms & Mean Difference & SD & Z value & p-value & Rmks \\
\cline { 2 - 7 } & GROUP A & GROUP B & & & & \\
\hline Shoola & 1.50 & 0.67 & 0.76 & 1.09 & 22.0 & IS \\
\hline Stambha & 1.50 & 0.37 & 0.49 & 0.47 & 0.68 & IS \\
\hline Shotha & 1.50 & 0.47 & 0.59 & 0.26 & 0.79 & IS \\
\hline
\end{tabular}




\begin{tabular}{|l|l|l|l|l|l|l|}
\hline $\begin{array}{l}\text { Prasarana } \\
\text { Aakunchana } \\
\text { Vedana }\end{array}$ & 1.50 & 0.80 & 0.68 & 1.35 & 0.177 & IS \\
\hline Atopa & 1.50 & 1.20 & 0.40 & 781 & 0.435 & IS \\
\hline VAS & 1.50 & 0.62 & 0.74 & 0.81 & 0.41 & IS \\
\hline WOMAC & 1.55 & 2.27 & 0.50 & 0.53 & 1 & IS \\
\hline
\end{tabular}

The result obtained after treatment in both groups was compared by MANN-WHITNEY U TEST. The result revealed that there is no significant difference between the effects of treatment in both groups.

\section{DISCUSSION ON MODE OF ACTION: -}

\section{ABHA GUGGULU: -}

* Abha Guggulu mainly acts on bones, joints, and parts of the musculoskeletal system. It mainly has Agnideepana, Vatahara, Shothahara, Vedanasthapana properties ${ }^{11}$.

* The Babbula present in it enhances bone regeneration and supports increased biomineralization $^{12}$.

* The Haritaki and Vibhitaki reduce bone inflammation and prevents bone resorption ${ }^{13}$.

* The Amalaki exerts potent antioxidant action, improves calcium absorption and its utility in the body and prevents bone destruction ${ }^{14}$.

* The Maricha, Pippali and shunti enhance the bioavailability of nutrients, boosts bone mineralization, reduces bone inflammation, alleviates pain $^{15}$.

* The Shuddha Guggulu reduces bone inflammation, alleviates pain, reduces swelling, pain and prevents bone resorption ${ }^{16}$.

* Guggulsterone is beneficial in the treatment of osteoarthritis and bone fractures, and it is a possible target for anti-inflammatory activity and reduces the activity of inflammatory responses ${ }^{17}$.

* Gallic acid and its derivatives are antiinflammatory agents that are effective in the treatment of osteoarthritis ${ }^{18}$.

* Linolic acid prevents cartilage degradation and bone resorption, while galactose regulates articular chondrocyte proteoglycan synthesis ${ }^{19}$.

* Piperine has been shown to slow the progression of $\mathrm{OA}^{20}$.
* Terpenoids have shown promise in modulating inflammatory mediators in the pathophysiology of arthritis ${ }^{21}$.

\section{YOGARAJA GUGGULU:-}

* It is an excellent medicine for the dry type of arthritis with degeneration of the joints due to excess Vata and deficiency of shlesaka kapha preventing the nourishment of the synovial flu$\mathrm{id}^{22}$.

* Plumbagin has been reported to exhibit analgesic and anti-inflammatory activity and prevents bone erosion directly inhibiting osteoclast formation ${ }^{23}$.

* Hyoscyamine is used to relieve mild to moderate symptoms of osteoarthritis ${ }^{24}$.

* Gallic acid and its derivatives are antiinflammatory agents have been reported to have potent effects on osteoarthritis treatment.

* Thymol exhibits potent anti-inflammatory activity by diminishing the release of inflammatory mediators ${ }^{25}$.

* Cuminaldehyde brings about wellness in OA patients by altering dysregulated inflammatory pathways $^{26}$.

* Vetiverol manages pain and muscular stiffness ${ }^{27}$.

* Piperine regulates the progression of OA.

* Moretenol is useful in different forms of arthritis and their different anti-inflammatory, antiarthritis properties have been evaluated for subjective improvement ${ }^{28}$.

* Delta- linanol inhibits infiltration of synovial membranes by inflammatory cells like macrophages, t- cells ${ }^{29}$.

* Linolic acid prevents cartilage degradation and bone resorption.

* Terpenoids are having promising effects in the modulation of inflammatory mediators in the pathophysiology of arthritis. 
* Tannins suppress inflammation and joint damage in $\mathrm{OA}^{30}$

* Cinnamate has been able to control OA pain by its anti-inflammatory activity.

* Cineol is effective in reducing pain, swelling, inflammation by inhibition of cytokine secretion by $\mathrm{T}$ lymphocytes. ${ }^{31}$

* Guggulsterone is useful in OA, bone fracture and has got a potential target for anti-inflammatory activity.

\section{CONCLUSION}

Vata is the controlling element in the body's preservation of balance. As age progresses, degeneration progresses with the influence of Vata, resulting in the process of progressive degeneration of the body. One of the consequences of this process, which is prevalent in elderly individuals is Sandhigata Vata. This is Kastasadhya and it is said that Mahagada takes place at Marma Asthi Sandhi. Janu is a Marma-Sandhi. In Charaka Samhita, it is clarified that Vata Dosha should be treated for the management of diseases at Marma Sthana. The analysis is intended to compare the effects of Abha Guggulu and Yogaraja Guggulu on Janu Sandhigata Vata. It can be concluded that both Abha Guggulu and Yogaraja Guggulu provided relief for most signs and symptoms other than Atopa after reviewing the research, observation, clinical trials, findings, and discussion. In both, groups signs and symptoms such as Shoola, Stambha, Shotha, Prasarana Aakunchana Vedana and parameters such as VAS, WOMAC decreased to a marked degree, which is highly significant statistically. Whereas no outcomes are seen in both categories, as in Atopa. There is no significant difference in the effect on signs and symptoms while comparing between the groups.

\section{REFERENCES}

1. R.K. Sharma, Bhagwan Dash, Charaka Samhita Uttarardha vol. revised Edition 2013, Chowkhamba Sanskrit Series Office, Varanasi, Chapter $28^{\text {th }}$, Shloka 37, Page .30.

2. Sir Stanley Davidson's Principles and Practice of
Medicine, edited by John A.A. Hunter et al, ${ }^{20 t}$ h edition, Churchill living stone, Chapter 25, Page 1096.

3. https:// www.ncbi.nlm.nih.gov

4. Dr. P. Himasagara Chandra Murthy, Sarangadhara Samhita of Sarngadharacarya, $2^{\text {nd }}$ Edition 2007, Chowkamba Press, Varanasi, Chapter $7^{\text {th }}$, Sloka $70-$ 81, Page 187and 188.

5. Dr. P. Himasagara Chandra Murthy, Sarangadhara Samhita of Sarngadharacarya, $2^{\text {nd }}$ Edition 2007, Chowkamba Press, Varanasi, Chapter $7^{\text {th }}$, Sloka 8487, Page. 188 and 189.

6. Dr. G. Prabhakar Rao, Cakra Datta Chikitsa Sangraha of Cakrapanidatta, First Edition 2014, Choukamba Orientalia, Varanasi, Chapter $25^{\text {th }}$, Sloka $.33-38$, Page 268.

7. API Textbook of Medicine, Edited by Siddharth $\mathrm{N}$ Shah, Volume 1, $8^{\text {th }}$ Reprint Edition, Association of Physicians of India, Chapter 5, Page 282.

8. www.ncbi.nlm.nih.gov

9. Priya Vat Sharma, Cakradatta, Edition 2007, Chaukhamba Orientalia, Varanasi, Chapter $49^{\text {th }}$, Sloka $14^{\text {th }}$, Page 387.

10. Dr G. Prabhakar Rao, Bhaisajya Ratnavali of Kaviraj Shri Govind Das Sen, First edition 2014, ChowkhambaOrientalia, Varanasi, Chapter $29^{\text {th }}$, Sloka 156-161, Page 836 and 837.

11. www.ncbi.nlm.nih.gov

12. ayurmedinfo.com.cdn.ampproject.org

13. www.easyayurveda.com

14. www.researchgate.net

15. www.medcraveonline.com

16. www.pubmed.ncbi.nlm.nih.gov

17. www.pubmed.ncbi.nlm.nih.gov

18. www.researchgate.net>publication

19. www.birmingham.ac.uk $>2019$

20. www.pubmed.ncbi.nlm.nih.gov

21. www.jrasccras.com $>$ doi $>$ pdf

22. www.pubmed.nlm.nih.gov

23. www.sciencedirect.com

24. www.sciencedirect.com

25. www.patent.google.com $>$ patent

26. www.researchgate.net>publication

27. www.researchgate.net>publication

28. www.sciencedirect.com $>$ article

29. www.mdpi.com>pdf

30. www.jrasccras.com $>$ doi $>$ pd

\section{Source of Support: Nil Conflict of Interest: None Declared}

How to cite this URL: Archana B.H. Jadav \& Susheel Shetty: A Comparative Clinical Study To Evaluate The Efficacy Of Abha Guggulu And Yogaraja Guggulu In Janu Sandhigata Vata. International Ayurvedic Medical Journal \{online\} 2021 \{cited September 2021\} Available from: http://www.iamj.in/posts/images/upload/1943 1950.pdf 